\title{
INFLUENCE OF STIMULATED PLASTICITY TRAINING METHOD ON COORDINATION INDICATORS OF HIGH PEDAGOGIC EDUCATIONAL ESTABLESHMENTS' GIRL STUDENTS
}

\author{
Kolumbet A.N.
}

Kiev National University of Technology and Design

\begin{abstract}
Purpose: study of stimulated plasticity training's influence on coordination indicators of pedagogic HEEs' girl students. Material: 264 girl students participated in the research. Experiment was being carried out during three years. Responding abilities, static and dynamic balance, orientation in space, promptness of operative thinking, volume of mechanical memorizing, distribution of attention, accuracy, quickness and of attention reswitching, accuracy of tasks' fulfillment were assessed. Results: it was found that plasticity has different kinds and forms of manifestation. Creative motor tasks require different conditions for their realization. We determined rates of plasticity increment by its main kinds. Plasticity of body movements was achieved at high level of different muscular groups' coordination, optimal rhythm, rational correlation of tension and relaxation. Conclusions: it was found that plasticity shall be trained in compliance with its kinds and manifestations. It requires appropriated approach to content of methodic of its perfection.
\end{abstract}

Key words: physical education, coordination abilities, plasticity, girl students.

\section{Introduction}

Higher school girl students' state and physical condition is the subject of serious researches of specialists. In opinion of the researchers modern practice of girl students' physical education does not ensure proper level of their physical, mental and cognitive abilities. To day such training is required for provisioning of specialists' real competition advantages at labor market. It is stressed in publications in periodic and scientific issues. Authors point at inadmissibly low effectiveness of physical education departments' functioning in state HEEs [2, 3, 6, 19, and 24].

In system of girl students' physical education special place is taken by training and improvement of coordination abilities, which are key ones in human mastering motor skills. Coordination is ensured by appropriate level of physical qualities' development (strength, quickness, flexibility of movements) [4, 8, 9, 16, 18, 22, and 33].

Coordination training permits to expand the range of girl students' adaptive potentials, considering individualgenetic characteristics. Adaptive reactions to physical load are conditioned by its character. That is why, when training and improving coordination it is necessary to differentiate them by their kinds and manifestations [1, 7, 25, 31].

When solving the problem of coordination's training and perfection, it is also necessary to consider morphological-functional characteristics of young organism, which determine its adaptive potentials [13, 14, 28, and 29]. Mobility of regulatory mechanisms permits to build training process on the base of early outlined laws of functional systems' heterochronic development.

The problems of training of coordination abilities have always been paid sufficient attention. The researches of a number of authors are devoted to perception of youth' coordination abilities [5, 10, 15, 17, 27, 36]. Alongside with it, the authors could not elucidate to the fullest extent the problems of plasticity training in pedagogic HEEs' girl students.

Purpose, tasks of the work, material and methods

The purpose of the work is to student influence of stimulated plasticity training during three years on coordination indicators of girl students.

The methods and organization of the research: the research was being conducted in 2008-2010. 264 of $1^{\text {st }}$ $-3^{\text {rd }}$ year girl students from Chernigov national pedagogic university, named after T.G. Shevchenko and Kiev University named after Boris Grinchenko participated in the research. All girl students were related to main health group.

(c) Kolumbet A.N., 2015

http://dx.doi.org/10.15561/20755279.2015.0604 
Girl students' accuracy was assessed with the help of the following tests: 1) accuracy of reproduction of set force value (with hand dynamometer); 2) accuracy of reproduction of set arms movements' amplitude (with kinematic meter of M. Zhukovskiy).

Responding abilities (dexterity) was assessed with the following tests: test for quickness of reaction (Catching of rule", S.A. Dushanin, 1978); 2) test for response to moving object. For this test computer program "Prognoz", worked out by Institute of physiology, named after A.A. Bogomolets, of Ukrainian AS was used. 3) test for quickness of visual motor response (simple and complex) (test "Catching of stick" of I.V. Afanasyev, 2008); 4) complex coordination test, oriented on determination of exact, differently oriented speed-power movements for certain time ( $\mathrm{t}$ computer program "Prognoz", worked out by Institute of physiology, named after A.A. Bogomolets, of Ukrainian AS, Kiev).

For estimation of ability to keep balance the following tests were used: 1) assessment of static balance (Romberg's test, "Stork" posture); 2) dynamic balance was estimated with test "Turns on gymnastic bench" (P. Khirts et al., 1985).

Orientation in space was checked with test "Labyrinth" (I.Yu. Gorskaya, 2000). Professionally important abilities were assessed with the following tests: 1) determination of attention distribution (test for "Finding digits", A. Sizanov, 2003); 2) volume of mechanical memorizing (test “Quantity of men figures”, A. Sizankv, 2003); 3) distribution of attention and quickness of operative thinking (assembling puzzles for certain time, I.V. Afanasyev, ,2008); 4) quickness of operative thinking (“Coss's cubes”, L.F. Burlachuk, 2000); 5) quickness and re-0switching of attention concentration, accuracy of task's fulfillment were determined on special device (S.I. Kirichenko, 1998).

\section{Results of the researches}

The methodic of plasticity training included complexes of motor tasks, mainly oriented on increment of some certain kind of it. Besides, we considered simultaneous impact of physical load on perfection of main characteristics of the studied coordination. For this purpose we used system of tests and assessment criteria [8, 11, $12,26]$. It permitted to sufficiently objectively measure the rates of plasticity increment by its main kinds. Great attention was paid to variability of muscular load, which was based on physical education program for pedagogic HEEs girl students. Wide usage of various physical exercises (as well as different conditions and means of their fulfillment, implementation of creative tasks) activated girl students' motor functioning, stimulated realization of their reserve potentials. In experimental groups all trainings were conducted with the help of play methods. Main attention was concentrated at development of body movements', upper girdle belt, lower limbs' and hands' plasticity.

To larger extent plasticity is intrinsic to junior age children. Natural plasticity disappears rather quickly, if it is not trained. For further its improvement special trainings are required. Materials of the research witness that usage of methodic of stimulated plasticity training permits to achieve increment of its indicators in girl students. Perfection of this coordination goes at different rates, depending on its kinds.

Analysis of body movements' plasticity did not show important differences between increment rates of experimental and control groups' girl students (see table 1).

Table 1. Increment of indicators (in \%) of different plasticity kinds

\begin{tabular}{|c|c|c|c|c|c|c|c|}
\hline \multirow[t]{2}{*}{ № } & \multirow[t]{2}{*}{ Tests } & \multirow[t]{2}{*}{$\begin{array}{l}\text { Period of } \\
\text { research }\end{array}$} & \multicolumn{2}{|c|}{ Control group } & \multicolumn{2}{|c|}{$\begin{array}{c}\text { Experimental } \\
\text { group }\end{array}$} & \multirow[t]{2}{*}{$\mathbf{p}$} \\
\hline & & & $\mathbf{M}$ & $\pm \mathbf{m}$ & $\mathbf{M}$ & $\pm \mathbf{m}$ & \\
\hline 1 & 2 & 3 & 4 & 5 & 6 & 7 & 8 \\
\hline \multirow{3}{*}{1} & Plasticity in fulfillment of & $1^{\text {st }}$ year & 0,52 & 0,03 & 0,62 & 0,04 & $>0,05$ \\
\hline & "forward wave" & $2^{\text {nd }}$ year & 0,44 & 0,03 & 0,52 & 0,03 & $>0,05$ \\
\hline & & $3^{\text {rd }}$ year & 0,47 & 0,03 & 0,51 & 0,03 & $>0,05$ \\
\hline \multirow{3}{*}{2} & Plasticity in fulfillment of & $1^{\text {st }}$ year & 0,84 & 0,06 & 5,86 & 0,40 & $<0,05$ \\
\hline & "wave" with arms forward" & $2^{\text {nd }}$ year & 0,58 & 0,06 & 5,83 & 0,32 & $<0,05$ \\
\hline & & $3^{\text {rd }}$ year & 0,66 & 0,06 & 6,27 & 0,38 & $<0,05$ \\
\hline & Plasticity in fulfillment of & $1^{\text {st }}$ year & 1,55 & 0,11 & 7,33 & 0,53 & $<0,05$ \\
\hline 3 & "wave" with hand & $2^{\text {nd }}$ year & 1,46 & 0,10 & 7,39 & 0,54 & $<0,05$ \\
\hline
\end{tabular}




\begin{tabular}{llllllll}
\hline & & $3^{\text {rd }}$ year & 1,31 & 0,08 & 8,14 & 0,58 & $<0,05$ \\
& Plasticity in fulfillment of & $1^{\text {st }}$ year & 4,03 & 0,30 & 7,29 & 0,47 & $<0,05$ \\
& forward -back leg movement & $2^{\text {nd }}$ year & 3,03 & 0,19 & 8,29 & 0,43 & $<0,05$ \\
& $3^{\text {rd }}$ year & 3,28 & 0,23 & 8,56 & 0,46 & $<0,05$ \\
& \multirow{2}{*}{ Plasticity in keeping of set } & $1^{\text {st }}$ year & 3,55 & 0,18 & 8,25 & 0,44 & $<0,05$ \\
& posture & $2^{\text {nd }}$ year & 3,15 & 0,17 & 9,59 & 0,55 & $<0,05$ \\
& $3^{\text {rd }}$ year & 3,50 & 0,20 & 9,90 & 0,60 & $<0,05$ \\
\hline
\end{tabular}

In stimulated training of upper limbs movements' plasticity rates of indicators' increment of experimental groups' girl students are ahead of control groups' indicators. It is connected with the fact that during rather long period of time girl students systemically fulfilled purposeful exercises. These exercises were oriented on training and strengthening of girdle belt muscles with simultaneous achievement of movements' expressiveness. Girl students were explained importance of the fulfilled exercises. Wide range of application of the received skills permitted to encourage interest to trainings.

Increment rates of hands movements' plasticity were lower in control groups. However, strengthening of small muscular groups with the help of special exercises and methodic permitted to sufficiently quickly influence favorably on development of this kind of plasticity.

Analysis of dynamic of indicators increment of lower limbs' movements showed average increment rates with natural and stimulated their development. It is connoted with gradual expansion of motor skills' range with fulfillment of different dance and choreographic exercises. Such exercises were the part of methodic of stimulated training of this kind of legibility and were characterized by higher dance fitness.

High mobility of nervous processes permits to quickly replace excitation processes by inhibition ones (alternate muscles' tension and relaxation). Application of special methodic ensured higher increment rates of the set posture plasticity in experimental groups' girl students

The level of their physical condition permitted to keep the set posture during required time, which achieved by regular practicing of exercises' system of play and competition methods. It permitted to strengthen back muscles and articular ligaments. Such approach is the basis for mastering different postures with accurate distinguishing of muscular tension's character. It is a necessary condition of movements' beauty and plasticity.

To master such motor actions it is necessary to have sufficient coordination: dexterity, accuracy, mobility, rhythm. Large and variable fund of motor actions permits to easier muster and extrapolate qualitatively new motor acts, which require their emotional perception and reproduction.

\section{Discussion}

Body movements' plasticity was achieved with high coordination of different muscular groups, optimal rhythm, rational correlation of tension and relaxation. It manifested in such movements as turns, bents, rotations, squatting [7, 11, and 20]. Different motor actions have specific means of expressiveness. For example, natural movements (run, jumps, throws) differ from gymnastic jumps, turns and acrobatic exercises. But all they have certain plasticity. That is why in the process of the research girl students' attention was accentuated on motor actions with maximal expressiveness, ease and grace.

Trainings' effectiveness is much higher with musical accompaniment [21, 26, 32]. Character of movements can be transmitted with the help of tambourine, different sound signals and claps. With it attention is accentuated on preparatory movements and on main link of motor action. In training great role shall be played by visual analyzer, basing on fulfillment of exercises at mirror. It permits for gi $\mathrm{rl}$ students to independently assess fulfillment of exercise and compare it with standard as well as to correct it, if required. Such approach helps for girl students to find the reasons of mistakes. Other important methodic technique is application of visual bench marks $[23,35]$. Girl students are keen for beauty and wish to reach it in music, art and dances. They start to see and understand it in movements. That is why girl students 'involvement in beautiful is an additional stimulus for them. Opportunity to enrich motor experience with new original movements at trainings increases girl students' interest.

Plasticity is a natural basis of aesthetic of any movements. It permits to transfer all gammas of feelings and emotions. Independent on difficulty of the fulfilled movement (simple step, jump, turn, dance movement) plasticity 
presents in all. At the dame time, plasticity manifestation depends on certain level of strength, quickness, endurance, dexterity, flexibility, mobility, accuracy. Depending on character and complexity of the fulfilled movement, different coordination qualities can be leading ones or additional [21, 37].

When training sport movements' technique instructors do not pay attention to special training of plasticity. The main reason of it is insufficient scientific-methodic provisioning [8, 30, 34]. That is why some instructors achieve girl students' high plasticity intuitively. Thus, it is necessary to develop natural plasticity and to improve them. Simultaneously it is required to educate girl students' strive for beauty. It will permit to assess any motor actions both by their technical complexity and by criteria of beauty.

\section{Conclusions}

Materials of our research showed that plasticity has different kinds and manifestations. Their improvement requires usage of various exercises. Creative motor tasks imply different conditions for their realization. For assessment of such tasks appropriate criteria are required. The received data witness, that plasticity shall be trained in compliance with its kinds and manifestations. It requires proper approach to content and methodic of its perfection.

Results of the research confirm that purposeful development of plasticity, considering its kinds and specific manifestations leads to improvement of its indicators with different increment rates. It positively reflected on physical fitness of experimental groups' girl students. At the same time the data of central nervous system's functional state improved.

In further publications we shall elucidate the methodic of stimulated training of girl students' other coordination qualities.

\section{Acknowledgement}

The researches were fulfilled in compliance with scientific program of physical education faculty of Chernigov national pedagogic university, named after T.G. Shevchenko. This program is a part of university topic "Didactic principles of motor function's formation in persons, who deal with physical education and sports" (state registration number $0108 \mathrm{U} 000854)$.

\section{Conflict of interests}

The author declares that there is no conflict of interests.

\section{References:}

1. Boloban VN. Reguliaciia pozy tela sportsmena [Regulation of sportsman's body posture], Kiev: Olympic Literature; 2013. (in Russian)

2. Bykov VA. Teoretiko-metodologicheskoe obosnovanie kompleksnoj sistemy sportivnoj podgotovki studentov vysshikh uchebnykh zavedenij fizicheskoj kul'tury [Theoretical-methodological substantiation of sport training complex system for students of physical culture higher educational establishments]. Teoriia $i$ praktika fizicheskoj kul'tury 2004; 2; 50-54.(in Russian)

3. Grigor'ev VI. Krizis fizicheskoj kul'tury studentov i puti ego preodoleniia [Crisis of students' physical culture and ways of its overcoming]. Teoriia i praktika fizicheskoj kul'tury 2004; 2; 54-61. (in Russian)

4. Grigor'eva SA. Ekspertnaia ocenka koordinacionnykh sposobnostej, professional'no-znachimykh dlia bakalavrov ekonomicheskogo profilia [Experts' assessment of coordination abilities, which are professionally important for bachalors of economic profile]. Uchenye zapiski 2011;vol.5(75); 47-50. (in Russian)

5. Zaporozhanov VA, Borchinski T. Sovershenstvovanie ocenki koordinacionnykh sposobnostej zanimaiushchikhsia fizicheskimi uprazhneniiami [Perfection of coordination's assessment of persons, practicing physical exercises]. Pedagogics, Psychology, Medical-Biological Problems of Physical Training and Sports 2009; 9; 52-55. (in Russian)

6. Klimakova SM. Analiz stanu fizichnogo vikhovannia u vishchikh navchal'nikh zakladakh [Analysis of physical education in higher educational establishments]. Pedagogics, Psychology, Medical-Biological Problems of Physical Training and Sports 2011; 8; 36-40. (in Ukrainian)

7. Kozhevnikova LK. Vospitanie koordinacionnykh sposobnostej na zaniatiiakh po fizicheskomu vospitaniiu [Training of coordination at lessons of physical education]. Physical Education of Students 2012; 1; 38-41. (in Russian)

8. Kolumbet OM. Rozvitok koordinacijnikh zdibnostej molodi [Development of youth's coordination abilities]. 
Kiev: Osvita Ukraine; 2014. (in Ukrainian)

9. Kolumbet OM. Teoretiko-metodichni pidkhodi do rozvitku koordinacijnikh zdibnostej molodi [Theoreticalmethodic approaches to development of youth's coordination abilities]. Pedagogics, Psychology, MedicalBiological Problems of Physical Training and Sports 2012; 4; 62-65. (in Ukrainian)

10. Kolumbet OM. Stimul'ovanij rozvitok koordinacijnikh zdibnostej majbutnikh uchiteliv-naochnikiv [Stimulated training of coordination abilities of future teachers]. Visnik Chernigivs'kogo nacional'nogo pedagogichnogo universitetu imeni T. G. Shevchenka 2013; 107; 228-230. (in Ukrainian)

11. Kolumbet OM. Metodika vdoskonalennia profesijno znachushchikh koordinacijnikh zdibnostej u studentok na zaniattiakh z fizichnogo vikhovannia [Methodic of improvement of students' professionally significant coordination abilities at physical education lessons]. Naukovo-pedagogichni problemi fizichnoi kul'turi 2013; 13(40); 109-116. (in Ukrainian)

12. Kolumbet AN. Klassifikaciia koordinacionnykh sposobnostej molodezhi, faktory i komponenty ikh razvitiia [Classification of youth's coordination abilities; factors and components of their development]. Aktual'nye problemy gumanitarnykh i estestvennykh nauk 2014; 4(2); 142-149. (in Russian)

13. Korobejnikov GV. Psikhofiziologicheskie mekhanizmy umstvennoj deiatel'nosti cheloveka [Psychophysiological mechanisms of human mental functioning], Kiev; 2002. (in Russian)

14. Lizogub VS. Individual'ni psikhofiziologichni osoblivosti liudini ta profesijna diial'nist' [Individual psychphysiological features of person and professional functioning]. Fiziologichnij zhurnal 2010;56(1):148-151. (in Ukrainian)

15. Lyakh VI. Vzaimootnoshenie koordinacionnykh sposobnostej i dvigatel'nykh navykov [Correlation of coordination abilities and motor skills]. Teoriia i praktika fizicheskoj kul'tury 1987;9:61-62. (in Russian)

16. Lyakh VI. Koordinacionnye sposobnosti [Coordination abilities]. Moscow: TVT Divizion; 2006. (in Russian)

17. Nazarenko LD. Sredstva i metody razvitiia dvigatel'nykh koordinacij [Means and methods of motor coordination training]. Moscow: Teoriia i praktika fizicheskoj kul'tury; 2003. (in Russian)

18. Tereschenko IA, Otsupok AP, Krupenio SV, Levchuk TM, Boloban VN. Evaluation of freshmen coordination abilities on practical training in gymnastics. Physical Education of Students, 2013;3:60-71. doi:10.6084/m9.figshare.663628

19. Bazylyuk TA. Self-evaluation of health and interests of students of higher education institutions on course physical education. Pedagogics, psychology, medical-biological problems of physical training and sports, 2013; 7; 3-6. doi:10.6084/m9.figshare.735943

20. Beliak YuI, Zinchenko NM. Dosing method of physical activity in aerobics classes for students. Physical Education of Students, 2014;5:8-13. doi:10.15561/20755279.2014.0502

21. Belykh SI. Structure of the concept of personality oriented physical education university students. Physical Education of Students, 2013;4:3-9. doi:10.6084/m9.figshare.669663.

22. Bryukhanova NA, Bulgakova OV, Mokrova TI, Bogashchenko YA. Determination of possibilities of the use of high-intensive trainings facilities on lessons health aerobics. Physical Education of Students, 2013;2:2529. doi:10.6084/m9.figshare. 156376 .

23. Furman YM, Salnikova SV. Improvement of aerobic energy supply processes in 37-49 yrs old women by means of complex aqua-fitness trainings' and methodic of endogenous - hypoxic breathing's application. Pedagogics, psychology, medical-biological problems of physical training and sports, 2015;7:59-63. http://dx.doi.org/10.15561/18189172.2015.0708.

24. Iermakov SS, Apanasenko GL, Bondarenko TV, Prasol SD. Physical culture is a basic instrument of culture of health. Pedagogics, psychology, medical-biological problems of physical training and sports, 2010; 11; 31-33.

25. Iermakov SS, Ivashchenko PI, Guzov VV. Features of motivation of students to application of individual programs of physical self-preparation. Physical Education of Students 2012; 4; 59-61.

26. Kolumbet AN. Physical education for the students of pedagogical specialities. III th International Research and Practice Conference "Science, Technology and Higher Education", Westwood: Canada; 2014. P. 34-42.

27. Kolumbet AN. Development of coordination abilities of young people. $V$ th International Research and Practice Conference "Science and Education”, Munich: Germany; 2014. P. 54-62. 
28. Korobeynikov GV. Psychophysiological Peculiarities of Sexual Dimorphism in Athletes. Psychologe Research 2012; 2; 6; 336-342.

29. Kozina ZL, Iermakov SS. Analysis of students' nervous system's typological properties, in aspect of response to extreme situation, with the help of multi-dimensional analysis. Physical Education of Students, 2015;3:1019. http://dx.doi.org/10.15561/20755279.2015.0302

30. Kurmaeva EV. Fitness - programs as mean of forming of personality physical culture of students. Physical Education of Students, 2013;1:37-39. doi:10.6084/m9.figshare.156355

31. Loewenstein VR. Handbook of Sensor. Physiology. Principles of Receptor Physiology. Berlin-HeidelbergNew York: Springer; 1992.

32. Martyniuk OV. Justification for experimental methods for circuit training aerobics classes first mature age women. Pedagogics, psychology, medical-biological problems of physical training and sports, 2014;11:3037. doi:10.15561/18189172.2014.1106

33. Masliak IP. Physical health of young and middle age women under influence of step-aerobics exercises. Pedagogics, psychology, medical-biological problems of physical training and sports, 2015;10:45-50. http://dx.doi.org/10.15561/18189172.2015.1007

34. Pogrebniak IM, Kudelko VE, Nagovitsina O P. Effect of improving aerobics classes at the level of flexibility of female students. Pedagogics, psychology, medical-biological problems of physical training and sports, 2013;5:49-52. doi:10.6084/m9.figshare.707099

35. Pop C, Ciomag V. The Influence of Aerobic Gymnastics on the Students' Body Image. Procedia - Social and Behavioral Sciences 2014; 117; 129-135.

36. Prusik Krzysztof, Prusik Katarzyna, Kozina ZhL, Iermakov SS. Features of physical development, physical preparedness and functional state of boys and girls - students of Polish higher educational establishments. Physical Education of Students, 2013;1:54-61. doi:10.6084/m9.figshare.96415

37. Rauner RR. Evidence that Aerobic Fitness Is More Salient than Weight Status in Predicting Standardized Math and Reading Outcomes in Fourth-through Eighth-Grade Students. The Journal of Pediatrics 2013; 163(2); 344-348. 


\section{Information about the author:}

Kolumbet A.N.; http://orcid.org/0000-0001-8775-4232; re play@3g.ua; Kiev National University of Technology and Design; st. NemirovichDanchenko, 2, Kiev, 14013, Ukraine.

Cite this article as: Kolumbet A.N. Influence of stimulated plasticity training method on coordination indicators of high pedagogic educational estableshments' girl students. Physical education of students, 2015;6:31-37. http://dx.doi.org/10.15561/20755279.2015.0604

The electronic version of this article is the complete one and can be found online at: http://www.sportpedu.org.ua/html/arhive-e.html

This is an Open Access article distributed under the terms of the Creative Commons Attribution License, which permits unrestricted use, distribution, and reproduction in any medium, provided the original work is properly cited (http://creativecommons.org/licenses/by/4.0/deed.en).

Received: 05.08.2015

Accepted: 20.08.2015; Published: 10.09.2015 